\title{
First report of tilapia lake virus emergence in fish farms in the department of Córdoba, Colombia
}

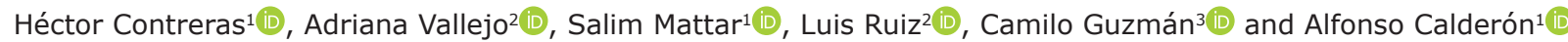

1. Institute of Biological Research of the Tropic, University of Córdoba, Colombia; 2. Aquatic Health and Water Quality laboratory, Aquaculture Program, University of Córdoba, Colombia; 3. Department of Pharmacy, Faculty of Health Sciences, University of Córdoba, Colombia.

Corresponding author: Salim Mattar, e-mail:smattar@correo.unicordoba.edu.co

Co-authors: HC: hectorcontrerasm@correo.unicordoba.edu.co, AV: avallejo@correo.unicordoba.edu.co,

LR: luiscarlosrg03@gmail.com, CG: cguzman40@hotmail.com, AC: acalderonr@correo.unicordoba.edu.co

Received: 26-04-2020, Accepted: 21-12-2020, Published online: 10-04-2021

doi: www.doi.org/10.14202/vetworld.2021.865-872 How to cite this article: Contreras H, Vallejo A, Mattar S, Ruiz L, Guzmán C, Calderón A (2021) First report of Tilapia lake virus emergence in fish farms in the department of Córdoba, Colombia, Veterinary World, 14(4): 865-872.

\begin{abstract}
Background and Aim: In 2016, the tilapia-producing farms in the department of Córdoba, Colombia, had witnessed outbreaks of disease with clinical signs compatible with those caused by the tilapia lake virus (TiLV). This study was conducted to confirm the presence of TiLV in some fish farms in the department of Córdoba.
\end{abstract}

Materials and Methods: A descriptive cross-sectional study was conducted in seven farms using a non-random sampling method from July 2016 to December 2017. A total of 66 fish, including 33 healthy fish and 33 fish with clinical signs, were caught, from which 178 tissue samples of spleen, liver, and brain were collected. RNA was extracted from each organ using TRIzol $^{\circledR}$. cDNA was synthesized using a retrotranscriptase and a universal amplification primer. The polymerase chain reaction was performed using primers specific to TiLV, in which the primers were amplified in a 491 bp region in segment 3 of TiLV, and the amplicons were sequenced using the Sanger method.

Results: Of the seven farms surveyed, 3 (42.85\%) had TiLV in the collected fish. Of the 66 collected fish, 18 (27.27\%) were infected with TiLV. The virus was detected in the brain $(64.3 \%, 18 / 28)$, spleen $(61.9 \%, 13 / 21)$, and liver $(35.7 \%$, 10/28). The sequences were recorded in GenBank with the codes MH338228, MH350845, and MH350846. Nucleotide homology analyses revealed that this study's circulating strains exhibited $97 \%$ identity with the Israeli strain (GenBank KU751816.1).

Conclusion: This is the first official report of TiLV in the department of Córdoba, Colombia. The circulating strains detected in this study exhibited $97 \%$ identity with the Israeli strain.

Keywords: alternative, animal use, developing countries, disease outbreaks, economic factor, fish diseases, sentinel surveillance.

\section{Introduction}

Tilapia (Oreochromis spp.) is considered the second most important species in aquaculture worldwide. The annual global production is estimated at 6.4 million metric tons valued at more than USD 9.8 billion, and it is expected that by the year 2030 , the production will increase to 7.3 million metric tons [1]. China, Ecuador, Egypt, Indonesia, and Thailand were the producers of this species, whose production was valued at USD 1.8 trillion in 2015. The United States has the top imports of this fish and consumes approximately 225 metric tons annually [2].

Tilapia is an economical source of protein, primarily in developing countries $[3,4]$. It is considered a fast-growing fish, relatively resistant to diseases [5],

Copyright: Contreras, et al. Open Access. This article is distributed under the terms of the Creative Commons Attribution 4.0 International License (http://creativecommons.org/licenses/ by/4.0/), which permits unrestricted use, distribution, and reproduction in any medium, provided you give appropriate credit to the original author(s) and the source, provide a link to the Creative Commons license, and indicate if changes were made. The Creative Commons Public Domain Dedication waiver (http:// creativecommons.org/publicdomain/zero/1.0/) applies to the data made available in this article, unless otherwise stated. although its production is threatened by some pathogenic microorganisms [6-8]. Massive deaths due to infectious etiologies have resulted in substantial economic losses [9]. Diseases occurring in fish farmed for commercial purposes have been primarily attributed to crop intensification; increase in chemical, biological, and physical factors; and stress triggering agents that influence fish physiology [10].

In 2014, a highly contagious emerging virus was reported for the $1^{\text {st }}$ time in Israel that was associated with mortality levels of $>80 \%$ in Oreochromis spp. This virus was termed the tilapia lake virus (TiLV) [11]. After its discovery, there had been isolated outbreaks with high mortalities in tilapia in fish farms in Ecuador [11,12], Israel [13], Egypt [14], Thailand [9,15], and more recently in India [16], Malaysia [17], Chinese Taipei [18], the Philippines [19], Mexico [20], Peru [21], and the United States [22], with substantial economic losses. Estimates from Egypt indicated a production loss of 98,000 metric tons, at a value of around USD 100 million, due to the "summer mortality" syndrome in 2015 , of which TiLV may have played a part $[14,23]$. 
TiLV is an RNA virus enveloped in a single segmented strand and a negative sense $[11,13,24]$. The RNA has 10 segments that code for 10 proteins; all segments have an open reading frame (ORF). Segment 1 is the longest and has ORFs with weak sequence homology to the PB1 subunit of the influenza virus $\mathrm{C}$ [25]. None of the other segments exhibit homology with any other known virus $[13,25]$. However, the conserved terminal regions of $5^{\prime}$ and $3^{\prime}$ are similar to the genomic organization of the Orthomyxoviridae family members [25].

Animals infected with TiLV show clinical signs such as lethargy, paleness, lack of appetite, skin lacerations, eye lesions, hepatic, cephalic, and splenic lesions $[11,13,15]$. TiLV in diseased fish tissues was reported in Colombia in the year 2017 [12].

Between 2016 and 2017, there were high mortality rates in fish in tilapia-producing farms in the department of Córdoba, Colombia, Caribbean area. The disease exhibited clinical signs compatible with those caused by TiLV, an epidemiological situation due to which the present study was conducted to confirm the presence of TiLV in some fish farms in the department of Córdoba, Colombia.

\section{Materials and Methods}

\section{Ethical approval}

The University of Cordoba follows strict requirements of the legislation on scientific research in biological diversity. Those involve collecting, capturing, hunting, fishing, manipulating the biological resource, and mobilizing in the national territory. The Institute of Biological Research of the TropicIIBT requested the Corporation of the Valleys of Sinú and San Jorge-CVS's local approval dated May 21, 2016.

\section{Type of study, period, and geographical area}

This was a descriptive cross-sectional study conducted using a convenience non-random sampling method from July 2016 to December 2017, a period during which outbreaks of a disease with high mortality of fish occurred in the department of Córdoba, area of the Colombian Caribbean (Figure-1). The study sites were seven fish farms located in Buenavista, Lorica, Sahagún, Momil, San Bernardo del Viento, and Ciénaga de Oro, whose annual average temperature was $28^{\circ} \mathrm{C}$, and annual average rainfall was $2000 \mathrm{~mm}$, with August-November being the rainiest months. The same numbers of diseased and healthy tilapia fish were collected from each farm, considering that they were from the same lot and culture pond. The distribution of the specimens was as follows: Momil $(\mathrm{n}=8)$, Buenavista $(\mathrm{n}=10)$, Lorica $(\mathrm{n}=10)$, Sahagún-1 $(\mathrm{n}=10)$, Sahagú-2 $(\mathrm{n}=8)$, San Bernardo del Viento $(\mathrm{n}=10)$, and Ciénaga de Oro $(n=10)$.

\section{Collection of samples}

Between 8 and 10 specimens of tilapia (Oreochromis spp.) were collected from each fish farm, resulting in a total of 66 fish comprising 33 healthy fish and 33 fish with clinical signs of disease. The fish were then anesthetized using eugenol $(1 \mathrm{ppm})$ and euthanized by a cervical puncture. The specimens were dissected in situ, avoiding cross-contamination between tissues and organs. A total of 178 tissue fragments were distributed as follows: 66 brain samples (Momil [ $\mathrm{n}=8]$, Buenavista $[\mathrm{n}=10]$, Lorica [n=10], Sahagún-1 [n=10], Sahagún-2 [n=8], San Bernardo del Viento [ $\mathrm{n}=10]$, and Ciénaga de Oro $[\mathrm{n}=10]$ ); 66 liver samples (Momil [ $\mathrm{n}=8]$, Buenavista $[n=10]$, Lorica [ $n=10]$, Sahagún-1 $[n=10]$, Sahagún-2 $[\mathrm{n}=8]$, San Bernardo del Viento [ $\mathrm{n}=10]$, and Ciénaga de Oro [ $\mathrm{n}=10]$ ); and 46 spleen samples (Momil [n=8], Buenavista [n=10], Lorica [n=5], Sahagún-1 [n=7], Sahagún-2 [n=6], San Bernardo del Viento [n=3], and Ciénaga de Oro $[\mathrm{n}=7])$. Tissues were placed in cryovials containing RNAlater ${ }^{\circledR}$ solution (Invitrogen, USA) and stored at $-80^{\circ} \mathrm{C}$ until processing. To maintain the anonymity of the farms, they were named after

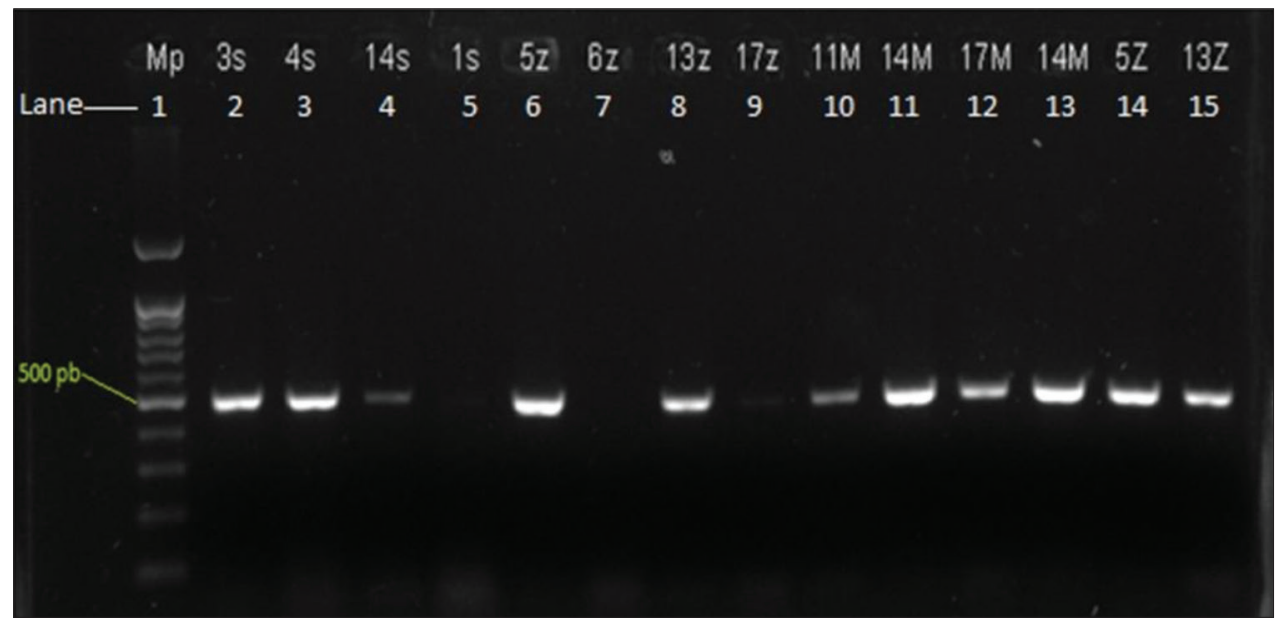

Figure-1: Agarose gels electrophoresis using SYBR safe with TiLV amplicons of Momil 1, Buenavista, and San Bernardo del Viento. Lane 1, molecular weight of 500 bp. Lanes 2-5 show TiLV amplicons from San Bernardo del Viento. Lanes 6, 8, 9, 14, and 15 show TiLV amplicons from Buenavista; lanes 10-13 show TiLV amplicons from Momil. Lane 7, negative sample. TiLV=Tilapia lake virus. 
the municipality where they were located as Momil, Ciénaga de Oro, Sahagún-1 and -2, San Bernardo del Viento, Buenavista, and Lorica. Similarly, the origin of fingerlings was named after the department of origin (Caldas, Meta, and Córdoba).

\section{Molecular methods for the detection of TiLV}

According to the manufacturer's instruction, approximately 50 and $100 \mathrm{mg}$ of each tissue samples were taken for RNA extraction using TRIzol ${ }^{\mathbb{}}$ (Invitrogen). The extracted RNA was suspended in nuclease-free ultrapure distilled water and stored at $-80^{\circ} \mathrm{C}$. The purity and concentration of total RNA were determined in each sample using the NanoDrop ${ }^{\circledR} 2000$ spectrophotometer (Thermo Scientific, USA). cDNA was synthesized using a retrotranscriptase (M-MLV ${ }^{\circledR}$ Promega, USA) according to the manufacturer's instruction and a universal primer of amplification (Random ${ }^{\circledR}$ Primer Promega). The conventional polymerase chain reaction was performed using the specific primers nested ext-1 (5'TATGCAGTACTTTCCCTGCC3') and nested ext-2 (5'TTGCTCTGAGCAAGAGTACC3') as described by Eyngor et al. [13], which amplify a 491 bp fragment of segment 3 of TiLV. Agarose electrophoresis was conducted using SYBR ${ }^{\circledR}$ Safe DNA gel stain (Invitrogen) in $1 \times$ TBE buffer. The obtained amplicons were sequenced using the Sanger method. The sequences were edited in the MEGA 6.06 program [26], and the similarity of the nucleotide fragment with the homologous position of the strain genomes available in the NCBI database was determined by BLAST. Consensus alignment of the sequences obtained in this study was performed with the GenBank data. Elaboration of the phylogenetic tree was performed using the Kimura 2-parameter model [26].

\section{Results}

Prevalence of TiLV in farms

A total of 66 fish were analyzed, including Momil $(\mathrm{n}=8)$, Buenavista $(\mathrm{n}=10)$, Lorica $(\mathrm{n}=10)$, Sahagún-1 $(n=10)$, Sahagún-2 $(n=8)$, San Bernardo del Viento $(\mathrm{n}=10)$, and Ciénaga de Oro $(\mathrm{n}=10)$, of which 33 fish showed clinical signs of TiLV disease, whereas the remaining 33 fish showed no signs. Among the 66 fish analyzed from seven farms, TiLV was detected in 18 fish (27, 27\%) in Momil (8), Buenavista (5), and San Bernardo del Viento (5) (Figure-1), with mortality rates between $30 \%$ and $87 \%$ (Tables- 1 and 2). Of these 18 TiLV-positive fish, 14 had at least one or two clinical signs of disease, and the remaining 4 fish had no apparent clinical signs. In the other two farms (Buenavista and San Bernardo del Viento), only fish with clinical signs of disease were positive for TiLV, which exhibited $50 \%$ morbidity (Tables-1 and 2) [13-17,21,24,27-29].

\section{Prevalence of TiLV in tissue}

TiLV was detected in 18 of $28(64.3 \%)$ brain samples collected from Momil $(\mathrm{n}=8)$, Buenavista $(\mathrm{n}=5)$, and San Bernardo del Viento $(\mathrm{n}=5)$; in 13 of 21 $(61.9 \%)$ spleen samples collected from Momil $(n=6)$, Buenavista $(n=5)$, and San Bernardo del Viento $(n=2)$; and in 10 of 28 (35.7\%) liver samples collected from Momil ( $\mathrm{n}=2)$, Buenavista $(\mathrm{n}=3)$, and San Bernardo del Viento $(n=5)$ (Figure-1). Fish collected from Momil came from the department of Caldas in the Andean mountains of Colombia, and the fingerlings collected from Buenavista and San Bernardo del Viento came from the department of Meta, an area near the Venezuelan border (Figure-2).

\section{Clinical presentation}

The fish collected from the three farms with TiLV exhibited clinical signs such as lethargy, anorexia, thin fish with empty stomachs and intestines, visceral congestion (ascites), hepatomegaly, inflammation and rupture of the gallbladder, pale body, eye lesions, eroded fins, and splenomegaly (Figure-3).

\section{Environmental variables}

During disease outbreaks in the fish farms of Momil-1, Buenavista, and San Bernardo del Viento,

Table-1: Dates sampling, geographical descriptions of farms, and PCR results per fish farm analyzed.

\begin{tabular}{|c|c|c|c|c|c|c|c|c|c|c|}
\hline $\begin{array}{l}\text { Sampling } \\
\text { date }\end{array}$ & Municipality - Farm & Age & $\begin{array}{l}\text { GM } \\
(\%)\end{array}$ & Seed'-origin & Population & $\begin{array}{l}\text { Sample } \\
\text { (N) }\end{array}$ & $\mathbf{A H}$ & CS & $\begin{array}{l}\text { Fishes } \\
\text { infected } \\
\text { PCR (+) }\end{array}$ & $\begin{array}{c}\text { Apparent } \\
\text { infection } \\
\text { prevalence }(\%)\end{array}$ \\
\hline $\begin{array}{l}\text { July 26, } \\
2016\end{array}$ & Momil-1 & $\mathrm{Ad}$ & 85 & Caldas & 100.000 & 8 & 4 & 4 & $8 / 8$ & 100 \\
\hline $\begin{array}{l}\text { September } \\
14,2016\end{array}$ & Buenavista & Ad & 87 & Meta & 5.000 & 10 & 5 & 5 & $5 / 10$ & 50 \\
\hline $\begin{array}{l}\text { November } \\
19,2016\end{array}$ & Lorica & $\mathrm{Al}$ & 30 & Caldas & 75.000 & 10 & 5 & 5 & $0 / 10$ & 0 \\
\hline $\begin{array}{l}\text { April 14, } \\
2017\end{array}$ & Sahagún-1 & Ad & 20 & Meta & 80.000 & 10 & 5 & 5 & $0 / 10$ & 0 \\
\hline $\begin{array}{l}\text { April 14, } \\
2017\end{array}$ & Sahagún-2 & $\mathrm{Al}$ & 45 & Meta & 100.000 & 8 & 4 & 4 & $0 / 8$ & 0 \\
\hline $\begin{array}{l}\text { April 16, } \\
2017\end{array}$ & S Bernar del Viento & $\mathrm{Al}$ & 30 & Meta & 14.000 & 10 & 5 & 5 & $5 / 10$ & 50 \\
\hline $\begin{array}{l}\text { June 26, } \\
2017\end{array}$ & Cienaga de Oro & Ad & 30 & Cordoba & 100.000 & 10 & 5 & 5 & $0 / 10$ & 0 \\
\hline Total & 7 & & & & 1.074 .000 & 66 & 28 & 28 & $18 / 66$ & 42.85 \\
\hline
\end{tabular}

$\mathrm{GM}=$ Gross mortality, $\mathrm{AH}=$ Apparently healthy, $\mathrm{CS}=$ With clinical signs, $\mathrm{Ad}=\mathrm{Adult}, \mathrm{Al}=$ Fingerlings, $\mathrm{PCR}=$ Polymerase chain reaction 
Table-2: Prevalence and mortality of TiLV in different countries.

\begin{tabular}{|c|c|c|c|c|c|}
\hline $\begin{array}{l}\text { Country } \\
\text { Year }\end{array}$ & $\begin{array}{l}\text { Positive sampling } \\
\text { locations/total }\end{array}$ & $\begin{array}{l}\text { Positive fishes/ } \\
\text { total sampled }\end{array}$ & Involved specie & $\%$ mortality & References \\
\hline $\begin{array}{l}\text { Israel } \\
2014\end{array}$ & $25 / 25$ & - & $\begin{array}{l}\text { S. galilaeus, } T \text {. zilli, } O \text {. aureus, } \\
\text { T. simonis intermedia y tilapia } \\
\text { híbrida } O \text {. niloticus } \times O \text {. aureus }\end{array}$ & $>80$ & [13] \\
\hline $\begin{array}{l}\text { Egypt } \\
2015\end{array}$ & $4 / 8$ & $52 / 207$ & O. niloticus & & {$[27]$} \\
\hline $\begin{array}{l}\text { Ecuador } \\
2017\end{array}$ & $1 / 1$ & $17 / 27$ & O. niloticus & 90 & [24] \\
\hline $\begin{array}{l}\text { Thailand } \\
2017\end{array}$ & $22 / 32$ & ND/325 & $\begin{array}{l}\text { (O. niloticus) and red hybrid } \\
\text { tilapia (Oreochromis spp.) }\end{array}$ & $20-90$ & {$[15]$} \\
\hline $\begin{array}{l}\text { Egypt } \\
2017\end{array}$ & $3 / 11$ & ND/33 & O. niloticus & 9.2 & {$[14]$} \\
\hline $\begin{array}{l}\text { India } \\
2018\end{array}$ & $3 / 3$ & ND/45 & O. niloticus & $80-90$ & {$[16]$} \\
\hline $\begin{array}{l}\text { Malaysia } \\
2018\end{array}$ & $1 / 1$ & $N R / 20$ & $\begin{array}{l}\text { Red hybrid tilapia ( } O \text {. } \\
\text { niloticus } \times O \text {. mossambicus) }\end{array}$ & 25 & {$[17]$} \\
\hline $\begin{array}{l}\text { Malaysia } \\
2018\end{array}$ & $1 / 1$ & $5 / 5$ & O. niloticus, $P$. schwanenfeldii & ND & [29] \\
\hline $\begin{array}{l}\text { Uganda } \\
2018\end{array}$ & $6 / 14$ & $10 / 83$ & O. niloticus & ND & {$[28]$} \\
\hline $\begin{array}{l}\text { Tanzania } \\
2018\end{array}$ & $4 / 4$ & $18 / 108$ & O. niloticus & ND & {$[28]$} \\
\hline $\begin{array}{l}\text { Peru } \\
2019\end{array}$ & $3 / 4$ & $4 / 27$ & O. niloticus & ND & {$[21]$} \\
\hline $\begin{array}{l}\text { Colombia } \\
\text { 2016-2017 }\end{array}$ & $3 / 7$ & $18 / 66$ & $\begin{array}{l}\text { Red hybrid tilapia } \\
\text { (Oreochromis spp.) }\end{array}$ & $30-87$ & $\begin{array}{l}\text { Present } \\
\text { study }\end{array}$ \\
\hline
\end{tabular}

$\mathrm{ND}=$ No data, TiLV=Tilapia lake virus, S. galilaeus=Sarotherodon galilaeus, $T$. zilli=Tilapia zilli, 0 . aureus=Oreochromis aureus, $T$. simonis intermedia=Tristramella simonis intermedia, O. niloticus=Oreochromis niloticus,

O. mossambicus=Oreochromis mossambicus, $P$. schwanenfeldii=Puntius schwanenfeldii

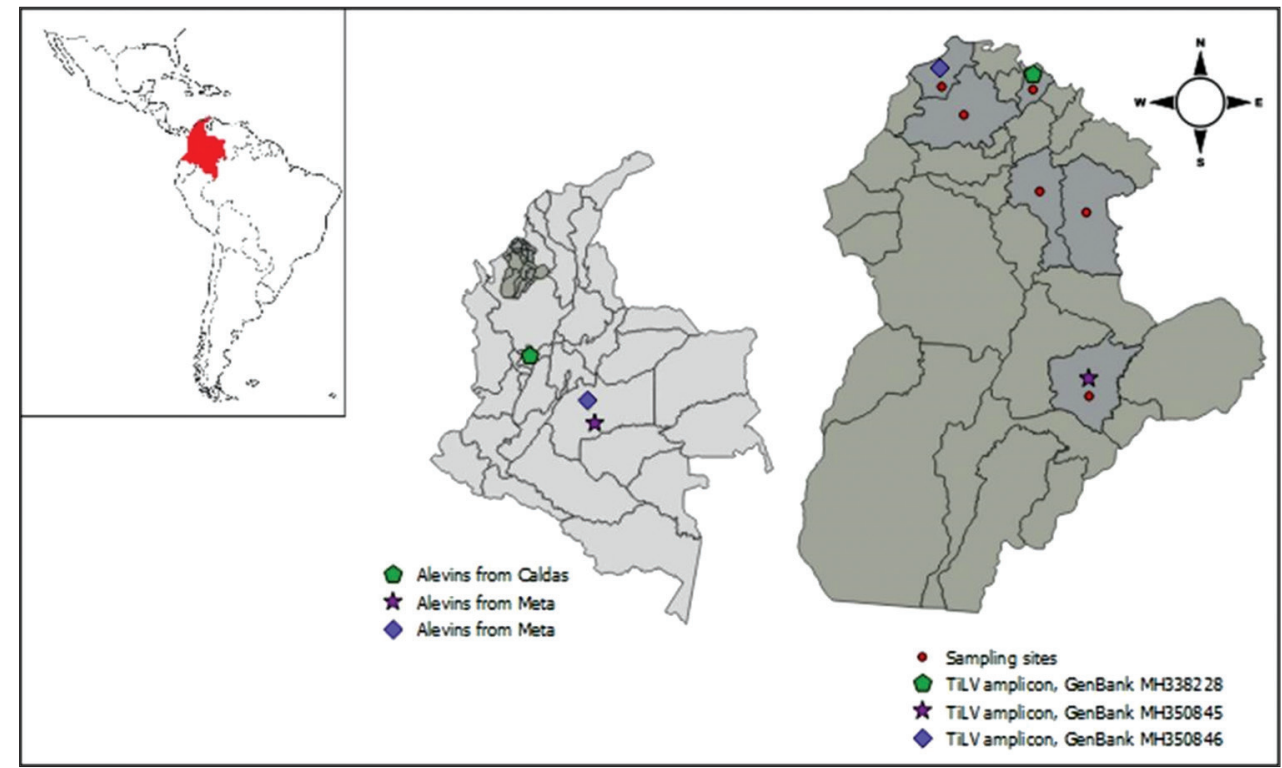

Figure-2: Sampling sites, origin of fingerlings, and the distribution of tilapia lake virus amplicons detected in the department of Córdoba [Source: The map was made using QGIS 2.18.22 "Las Palmas" Program, Spain].

the average temperatures were $27.5^{\circ} \mathrm{C}, 32.0^{\circ} \mathrm{C}$, and $28.0^{\circ} \mathrm{C}$, respectively. The average dissolved oxygen contents were $5.0 \mathrm{mg} / \mathrm{L}$ in Momil-1, $5.85 \mathrm{mg} / \mathrm{L}$ in Buenavista, and $9.0 \mathrm{mg} / \mathrm{L}$ in San Bernardo del Viento. In the Momil-1 fish farm, the concentration of nitrite during the outbreak period was $0.75 \mathrm{mg} / \mathrm{L}$. Variables such as $\mathrm{pH}$, ammonium, nitrites, water hardness, alkalinity, and chlorides showed no considerable variations on the farms.
Nucleotide and amino acid analysis of TiLV segment 3 sequences compared with GenBank sequences

The six sequences obtained in this study demonstrated $97 \%$ consensus identity with the sequence of segment 3 of the TiLV strain detected in tilapia from Israel in 2014 (GenBank KU751816.1) [13]. Three of the six sequences were deposited in GenBank, with the access codes MH338228 (Momil), MH350845 (Buenavista), and MH350846 (San Bernardo del 
Viento). The sequences obtained in this study showed eight different nucleotide changes at positions 330, $412,414,489,567,573,612$, and 726, concerning the phylogenetically closest sequence of TiLV segment 3 (GenBank KU751816.1_Israel) and with other GenBank sequences (KJ605629 Israel, KY381578 Thailand, MF582636_India, MF502419 India, and KX631923_Thailand). The sequences of the strains isolated from Momil-1 and San Bernardo del Viento displayed different nucleotide changes at positions $327,609,747$, and 659. The nucleotide change at position 412 of all sequences demonstrated a non-synonymous substitution that produced a change in amino acid 138 from glutamic acid to lysine (E138K). Sequencing of the San Bernardo del Viento strain revealed nine nucleotide changes at position 659; a non-synonymous substitution produced a shift in amino acid 220 from valine to alanine (V220A).

\section{Nucleotide distances}

The sequence closest to Colombian strains based on nucleotide identity was segment 3 of the Israeli strain (GenBank KU751816.1). The lowest degree of divergence with the Israeli strain was shown by the Buenavista sequence (GenBank MH350845) (divergence $=0.02462$ ), and the maximum degree of divergence was shown by the sequence from Momil-1 (GenBank MH338228) (divergence $=0.03155$ ). The most significant divergence of this study's sequences was observed with the Thai strain (GenBank KY381578). There was also a slight divergence between the sequences of the strains from Buenavista and San Bernardo del Viento (divergence $=0.002193$ ), and these two strain sequences, in turn, exhibited a higher degree of divergence with the Momil-1 strain. The most significant divergence between the sequences of the department of Córdoba was observed between Momil-1 and San Bernardo del Viento strains (divergence $=0.008830$ ). The two sequences of the same fish farm strains exhibited $100 \%$ identity (degree of divergence $=0.0$ ).

\section{Phylogenetic tree}

Phylogenetic reconstruction of TiLV was conducted using a $458 \mathrm{bp}$ fragment of segment 3 . For constructing the phylogenetic tree, the distances between homologous sequences were calculated using the Kimura 2-parameter model. The phylogenetic tree was constructed using the maximum likelihood method. The confidence values for the resulting tree's branches were determined by bootstrap analysis with 1000 repetitions.. Three sequences were obtained in this study and six downloaded from GenBank were confronted. The phylogenetic analysis confirmed the relationship between the strains of the department of Córdoba and the strains of Israel (GenBank KU751816.1) (Figure-4).

\section{Discussion}

This study demonstrated morbidity rates of $50-100 \%$ and mortality rates of $30-87 \%$ in each fish

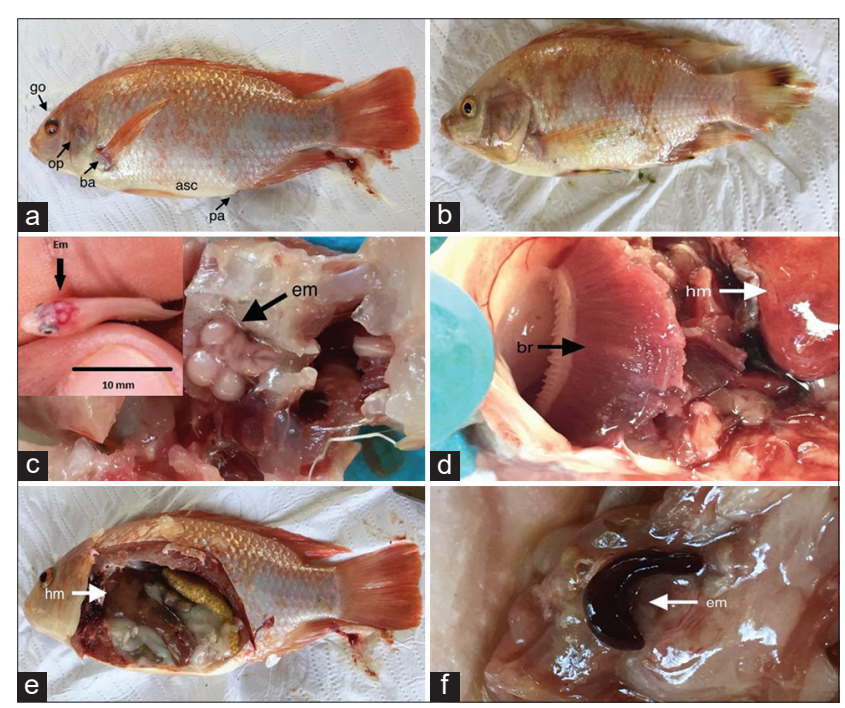

Figure-3: (a) Red hybrid tilapia with hemorrhagic eyeball (go), hemorrhagic operculum (op), the base of hemorrhagic fins (ba), ascites (asc), and congestive anal pore (pa). (b) Red tilapia (Oreochromis sp.) with discoloration and diffuse hemorrhagic congestion on the skin, nostril, and base of fins, fin necrosis, (c) red hybrid tilapia with encephalomegaly (em) in adult and fingerling (Em). (d) Fused and necrotic gills (br); hepatomegaly (hm), (e) red hybrid tilapia with hepatomegaly $(\mathrm{hm})$ (female ovate). (f) Splenomegaly (em). (Photos from one of the authors A. Vallejo-Isaza).

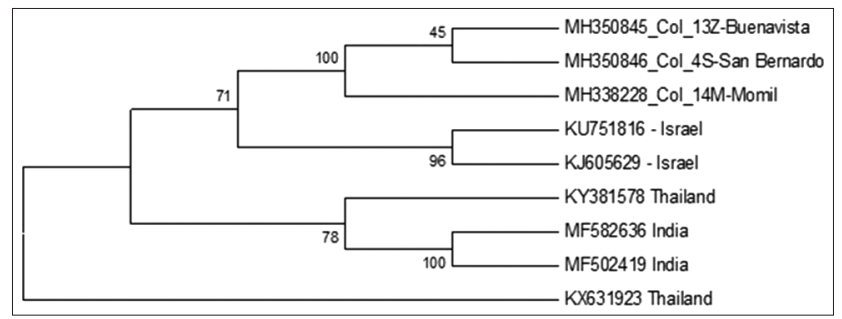

Figure-4: Comparing phylogenetic sequences of segment three of tilapia lake virus amplicons detected in Cordoba.

farm. The prevalence of TiLV infection is low and increases when massive mortalities are observed $[14,15,30]$. Results of the present study revealed $27.27 \%(18 / 66)$ prevalence of TiLV, indicating a more significant prevalence than that reported in Peru [21] at $14.8 \%(4 / 27)$ but lower than that reported in Ecuador [11], which was 63\% (17/27).

It has been reported that fish viral infections can be spread horizontally within the crop, with an infection rate of $100 \%$ in just 8 days [13]. In the present study, it was observed that healthy fish were not infected with TiLV, even when cohabiting with infected fish in the majority of cases. This could be because fish that survived initial infection with TiLV developed immunity to the virus [13]. A recent study showed that tilapia that survived TiLV infection develop protective immunity that prevents subsequent infection [31]. The farmed fish in the present study exhibited a wide variety of clinical signs along with high mortality. The severity of the disease might be related to other pathogens; however, none of the farms considered infections with pathogens other than 
TiLV. Coinfection of TiLV and Aeromonas veronii in red tilapia was reported in 2018 by a previous study, wherein it was presumed that the interaction between these two pathogens was synergistic, thus increasing the disease severity [17]. Another study also reported the coinfection of TiLV and $A$. veronii in addition to Aeromonas enteropelogenes and Aeromonas hydrophila in 2017 [27]. Moreover, a recent study reported that coinfection of TiLV and $A$. hydrophila increased mortality and worsened disease severity in tilapia (Oreochromis spp.) [32]. In the present study, TiLV was detected in four healthy fish. Similar results have been reported in apparently healthy tilapia, wherein the authors considered this condition healthy at a low viral load but with a potential for transmission [21,33].

The mortality rates in the adult specimens of hybrid red tilapia (Oreochromis spp.) collected from the farms of Momil-1 and Buenavista were $85 \%$ and $87 \%$, respectively, in this study, which is consistent with the previous reports $[9,13]$. In San Bernardo del Viento's fish farm, a mortality rate of $20 \%$ was detected in red tilapia fingerlings, similar to that reported by Dong et al. [9].

In the present study, the liver, spleen, and brain tissue samples collected from fish with TiLV infection showed the disease's clinical signs. Del-Pozo et al. [24] described the brain and liver as target organs of the virus; specifically, syncytial hepatitis has been described as a classic pathological finding of infection. Other authors have also described the brain as a target organ for TiLV [15,16,34]. We also observed that TiLV was present in $100 \%$ of the brain samples of tilapia with clinical signs of disease from the three positive farms, which allows confirming the tropism of the virus by this tissue. However, other authors did not detect TiLV in brain tissues [28]. Our results were inconsistent with those reported by Mugimba et al. [28], who did not detect TiLV in the brain tissue. However, Dong et al. [9] concluded that TiLV could be detected in the brain, gills, kidneys, liver, and spleen, and, more recently, it was also detected in reproductive organs [35]. On the other hand, we can argue that TiLV can cause a multisystemic infection, which may vary according to age, disease stage, and probably environmental aspects.

The genetic variation of TiLV observed in our study and other studies $[9,25,36]$ could be related to the segmented genome's feature. The genome allows mutations due to mixed infections caused by different viruses from different vertebrate animals, including human beings [37]. In the present study, it was observed that the variation of nucleotides at position 412 of the Colombian sequences showed a change at position 130 of the amino acid sequence of the protein. These changes in both nucleotides and amino acids of the TiLV strains detected within the same country were described for segments 1 , 5, and 9 in the TiLV strains detected in Thailand [9,30].

TiLV infections exhibit differences in clinical presentation and organotropism, which could be associated with nucleotide mutations that can affect genome functions, proteins, and receptor specificity.
This phenomenon would imply that there are genetic variants of TiLV with positive tropism for different tissues, as reported for the infectious salmon anemia virus with variations in virulence and cell tropism [38-40].

This study's TiLV sequences revealed 95\% identity with the TiLV segment 3 described in India (GenBank MF574205.1) [16]. However, it exhibited $97 \%$ identity with segment 3 of the Israeli strain (GenBank KU751816.1) [25]. Analysis of the TiLV genome's partial sequences from different countries has revealed genetic variations $[9,25,36]$. Therefore, it is possible that the sequences obtained in this study also show nucleotide variations compared to those of the strains of Israel registered in GenBank. Our study results suggest that segment 3 of TiLV strain detected in Colombia is highly similar to that of TiLV segment 3 of Israel; however, the entry route remains unknown.

\section{Conclusion}

To the best of our knowledge, this is the first report from the department of Córdoba confirming the molecular detection of TiLV. Moreover, this study demonstrates some possible foci of TiLV infection in Colombia. Analysis of segment 3 of the TiLV genome revealed new mutations, which could control the TiLV outbreaks in Colombia.

\section{Data Availability Statement}

Consensus DNA sequences are available at the National Center of Biotechnology Information (Accession Numbers MH338228, MH350845, and MH350846).

\section{Authors' Contributions}

$\mathrm{HC}$ : Designed the study, writing of the manuscript, and analyzed the data. AV, LR, CG and AC: Helped in the practical experiment, drafted the manuscript and analyzed the data. SM: Helped in the design of the study, supervised, and drafted the manuscript. All authors read and approved the final manuscript.

\section{Competing Interests}

The authors declare that they have no competing interests.

\section{Acknowledgments}

We are grateful to the staff involved in the sampling of tilapia in Cordoba and the farms sampling owners. This work was supported by Departamento de Ciencia Tecnología e Innovación (COLCIENCIAS), Ac. 26 \#57-41, Bogotá, Colombia, call 761-2016 and the Universidad de Cordoba through cooperation agreement 219 of 2017 . The present work was a postgraduate study (Master in Tropical Microbiology) of Hector Contreras.

\section{Competing Interests}

The authors declare that they have no competing interests. 


\section{Publisher's Note}

Veterinary World remains neutral with regard to jurisdictional claims in published map and institutional affiliation.

\section{References}

1. Harvey, D. (2015) Aquaculture Trade-Recent Years and Top Countries. United States Department of Agriculture, Washington, DC.

2. FAO Statistics and Information Branch, Fisheries and Aquaculture Department. (2017) Global Production by Production Source 1950-2015 (FishstatJ), Roma. Available from: http://www.fao.org/fishery/statistics/software/fishstatj/en. Retrieved on 26-10-2019.

3. Cleasby, N., Schwarz, A.M., Phillips, M., Paul, C., Pant, J., Oeta, J., Pickering, T., Meloty, A., Laumani, M. and Kori, M. (2014) The Socio-economic context for improving food security through land based aquaculture in Solomon islands: A peri-urban case study. Mar. Policy, 45(3): 89-97.

4. Gomna, A. (2011) The role of tilapia in food security of fishing villages in Niger state, Nigeria. Afr. J. Food. Agric. Nutr. Dev., 11(7): 5561-5572.

5. Ariel, E. and Owens, L. (1997) Epizootic mortalities in tilapia Oreochromis mossambicus. Dis. Aquat. Organ., 29(1): $1-6$.

6. Dong, H.T., Nguyen, V.V., Le, H.D., Sangsuriya, P., Jitrakorn, S., Saksmerprome, V., Senapin, S. and Rodkhum, C. (2015) Naturally concurrent infections of bacterial and viral pathogens in disease outbreaks in cultured Nile tilapia (Oreochromis niloticus) farms. Aquaculture, 448(14): 427-435.

7. El-Sayed, A.F.M. (2006) Tilapia Culture. CABI Publishing, Willingford, Oxfordshire, United Kingdom.

8. Kayansamruaj, P., Pirarat, N., Katagiri, T., Hirono, I. and Rodkhum, C. (2014) Molecular characterization and virulence gene profiling of pathogenic Streptococcus agalactiae populations from tilapia (Oreochromis Sp.) Farms in Thailand. J. Vet. Diagn. Invest., 26(4): 488-495.

9. Dong, H.T., Siriroob, S., Meemetta, W., Santimanawong, W., Gangnonngiw, W., Pirarat, N., Khunrae, P., Rattanarojpong, T., Vanichviriyakit, R. and Senapin, S. (2017) Emergence of tilapia lake virus in Thailand and an alternative semi-nested RT-PCR for detection. Aquaculture, 476(11): 111-118.

10. Awad, E.S. (2010) Studies on Plant Based Dietary Supplements for Control of Aeromonas Hydrophila Infections in Rainbow Trout (Oncorhynchus mykiss Walbaum). Heriot-Watt University, United Kingdom.

11. Ferguson, H.W., Kabuusu, R., Beltran, S., Reyes, E., Lince, J.A. and Del Pozo, J. (2014) Syncytial hepatitis of farmed tilapia, Oreochromis niloticus (L.): A case report. $J$. Fish Dis., 37(6): 583-589.

12. Tsofack, J.E.K., Zamostiano, R., Watted, S., Berkowitz, A., Rosenbluth, E., Mishra, N., Briese, T., Lipkin, W.I., Kabuusu, R.M. and Ferguson, H. (2017) Detection of tilapia lake virus in clinical samples by culturing and nested reverse transcription-PCR. J. Clin. Microbiol., 55(3): 759-767.

13. Eyngor, M., Zamostiano, R., Tsofack, J.E.K., Berkowitz, A., Bercovier, H., Tinman, S., Lev, M., Hurvitz, A., Galeotti, M. and Bacharach, E. (2014) Identification of a novel RNA virus lethal to tilapia. J. Clin. Microbiol., 52(12): 4137-4146.

14. Fathi, M., Dickson, C., Dickson, M., Leschen, W., Baily, J., Muir, F., Ulrich, K. and Weidmann, M. (2017) Identification of tilapia lake virus in Egypt in Nile tilapia affected by 'summer mortality’ syndrome. Aquaculture, 473(8): 430-432.

15. Surachetpong, W., Janetanakit, T., Nonthabenjawan, N., Tattiyapong, P., Sirikanchana, K. and Amonsin, A. (2017) Outbreaks of tilapia lake virus infection, Thailand, 20152016. Emerg. Infect. Dis., 23(6): 1031-1033.
16. Behera, B.K., Pradhan, P.K., Swaminathan, T.R., Sood, N., Paria, P., Das, A., Verma, D.K., Kumar, R., Yadav, M.K. and Dev, A.K. (2018) Emergence of tilapia lake virus associated with mortalities of farmed Nile tilapia Oreochromis niloticus (Linnaeus 1758) in India. Aquaculture, 484(3): 168-174.

17. Amal, M.N.A., Koh, C.B., Nurliyana, M., Suhaiba, M., Nor-Amalina, Z., Santha, S., Diyana-Nadhirah, K.P., Yusof, M.T., Ina-Salwany, M.Y. and Zamri-Saad, M. (2018) A case of natural co-infection of tilapia lake virus and Aeromonas veronii in a Malaysian red hybrid tilapia (Oreochromis niloticus $\times$ O. mossambicus) farm experiencing high mortality. Aquaculture, 485(4): 12-16.

18. World Organisation for Animal Health (OIE). (2019) Tilapia Lake Virus Disease, Chinese Taipei. Immediate Notification. World 287 Organisation for Animal Health (OIE), Rome. Available from: http://www.oie.int/wahis 2/ public/wahid.php/reviewreport/review?reportid=24033 . Retrieved on 29-10-2019.

19. World Organisation for Animal Health (OIE). (2019) Tilapia Lake Virus (TiLV), Philippines. World Organisation for Animal Health 290 (OIE), Immediate Notification, Philippines. Available from: http://www.oie.int/wahis_2/ public/wahid.php/reviewreport/review?page_refer=mapfulleventreport\&reportid=25278. Retrieved on 12-11-2019.

20. World Organisation for Animal Health (OIE). (2018) Tilapia Lake Virus (TiLV). Mexico, World Organisation for Animal Health (OIE), Immediate Notification. Available from: https://www.oie.int/wahis_2/public/wahid.php/ reviewreport/review?page refer=mapfulleventreport\&reportid=27650. Retrieved on 13-11-2019.

21. Pulido, L.L.H., Chìo, M.M., Chaparro, A.L.H., Dong, H.T. and Senapin, S. (2019) Tilapia lake virus (TiLV) from Peru is genetically close to the Israeli isolates. Aquaculture, 510(13): 61-65.

22. Ahasan, M.S., Keleher, W., Giray, C., Perry, B., Surachetpong, W., Nicholson, P., Al-Hussinee, L., Subramaniam, K. and Waltzek, T.B. (2020) Genomic characterization of tilapia lake virus isolates recovered from moribund Nile tilapia (Oreochromis niloticus) on a farm in the United States. Microbiol. Resour. Announc., 9(4): e01368-e01419.

23. Jansen, M.D., Dong, H.T. and Mohan, C.V. (2019) Tilapia lake virus: A threat to the global tilapia industry? Rev. Aquac., 11(3): 725-739.

24. Del-Pozo, J., Mishra, N., Kabuusu, R., Cheetham, S., Eldar, A., Bacharach, E., Lipkin, W.I. and Ferguson, H.W. (2017) Syncytial hepatitis of tilapia (Oreochromis niloticus L.) is associated with orthomyxovirus-like virions in hepatocytes. Vet. Pathol., 54(1): 164-170.

25. Bacharach, E., Mishra, N., Briese, T., Zody, M.C., Tsofack, J.E.K., Zamostiano, R., Berkowitz, A., Ng, J., Nitido, A. and Corvelo, A. (2016) Characterization of a novel orthomyxo-like virus causing mass die-offs of tilapia. MBio, 7(2): e00431-e00516.

26. Kimura, M. (1980) A simple method for estimating evolutionary rates of base substitutions through comparative studies of nucleotide sequences. J. Mol. Evol., 16(2): 111-120.

27. Nicholson, P., Fathi, M.A., Fischer, A., Mohan, C., Schieck, E., Mishra, N., Heinimann, A., Frey, J., Wieland, B. and Jores, J. (2017) Detection of tilapia lake virus in Egyptian fish farms experiencing high mortalities in 2015. J. Fish Dis., 40(12): 1925-1928.

28. Mugimba, K.K., Chengula, A.A., Wamala, S., Mwega,E.D., Kasanga, C.J., Byarugaba, D.K., Mdegela, R.H., Tal, S., Bornstein, B. and Dishon, A. (2018) Detection of tilapia lake virus (TiLV) infection by PCR in farmed and wild Nile tilapia (Oreochromis niloticus) from lake victoria. J. Fish Dis., 41(8): 1181-1189.

29. Abdullah, A., Ramly, R., Ridzwan, M.S.M., Sudirwan, F., Abas, A., Ahmad, K., Murni, M. and Kua, B.C. (2018) First detection of tilapia lake virus (TiLV) in wild river 
carp (Barbonymus schwanenfeldii) at timah tasoh lake, Malaysia. J. Fish Dis., 41(9): 1459-1462.

30. Surachetpong, W., Roy, S.R.K. and Nicholson, P. (2020) Tilapia lake virus: The story so far. J. Fish Dis., 43(10): $1115-1132$.

31. Tattiyapong, P., Dechavichitlead, W., Waltzek, T.B. and Surachetpong, W. (2020) Tilapia develop protective immunity including a humoral response followingexposure to tilapia lake virus. Fish Shellfish Immunol., 106(11): 666-674.

32. Nicholson, P., Mon-On, N., Jaemwimol, P., Tattiyapong, P. and Surachetpong, W. (2020) Coinfection of tilapia lake virus and Aeromonas hydrophila synergistically increased mortality and worsened the disease severity in tilapia (Oreochromis spp.). Aquaculture, 520(7): 734746.

33. Senapin, S., Shyam, K.U., Meemetta, W., Rattanarojpong, T. and Dong, H.T. (2018) Inapparent infection cases of tilapia lake virus (TiLV) in farmed tilapia. Aquaculture, 487(6): 51-55.

34. Tattiyapong, P., Dachavichitlead, W. and Surachetpong, W. (2017) Experimental infection of tilapia lake virus (TiLV) in Nile tilapia (Oreochromis niloticus) and red tilapia (Oreochromis spp.). Vet. Microbiol., 207(10): 170-177.

35. Yamkasem, J., Tattiyapong, P., Kamlangdee, A. and
Surachetpong, W. (2019) Evidence of potential vertical transmission of tilapia lake virus. J. Fish Dis., 42(9): 1293-1300.

36. Dong, H.T., Ataguba, G.A., Khunrae, P., Rattanarojpong, T. and Senapin, S. (2017) Evidence of TiLV infection in tilapia hatcheries from 2012 to 2017 reveals probable global spread of the disease. Aquaculture, 479(14): 579-583.

37. Manjarrez, M.E. and Arenas, G. (1999) Influenza virus. Past and present riddle. J. Nat. Inst. Respir. Dis., 12(4): 290-299.

38. Cottet, L., Rivas-Aravena, A., Martin, M.C.S., Sandino, A.M. and Spencer, E. (2011) Infectious salmon anemia virus-genetics and pathogenesis. Virus Res., 155(1): 10-19.

39. Christiansen, D.H., Østergaard, P.S., Snow, M., Dale, O.B. and Falk, K. (2011) A low-pathogenic variant of infectious salmon anemia virus (ISAV-HPR0) is highly prevalent and causes a non-clinical transient infection in farmed Atlantic salmon (Salmo salar L.) in the Faroe islands. J. Gen. Virol., 92(4): 909-918.

40. Christiansen, D.H., McBeath, A.J.A., Aamelfot, M., Matejusova, I., Fourrier, M., White, P., Petersen, P.E. and Falk, K. (2017) First field evidence of the evolution from a non-virulent HPR0 to a virulent HPR-deleted infectious salmon anaemia virus. J. Gen. Virol., 98(4): 595-606. 